\title{
PERAN DPD DALAM PENERAPAN ASAS DESENTRALISASI PADA SISTEM OTONOMI DAERAH
}

\author{
Bayu Dwiwiddy Jatmiko \\ Fakultas Hukum Universitas Muhammadiyah Malang \\ J1. Raya Tlogomas No. 246, Malang \\ Email: bayu.dj15@yahoo.com
}

\begin{abstract}
According to the Indonesian constitutional authority of DPD system is still very limited. All tasks and authority of DPD limited to the aspects that are closely linked with the area. Nevertheless, the Council position is not aligned with the Parliament; therefore need to be reviewed in the Council's role in the decentralized system of regional autonomy. So as to encourage the establishment of legislation to the maximum this is more favorable to the region and the well-being of the people in the area.
\end{abstract}

Keywords: DPD, Decentralization, Regional Autonomy.

\begin{abstract}
Abstrak
Menurut sistem ketatanegaraan Indonesia kewenangan DPD masih sangat terbatas. Semua tugas dan wewenang DPD terbatas pada aspek-aspek yang terkait erat dengan daerah. Meskipun demikian, kedudukan DPD tidaklah sejajar dengan DPR, Karenanya perlu dikaji peran DPD dalam sistem desentralisasi di era otonomi daerah. Sehingga mampu mendorong terwujudnya pembuatan perundang-undangan secara maksimal yang lebih memihak kepada daerah dan kesejahteraan rakyat di daerah.
\end{abstract}

\section{Kata Kunci: DPD, Desentralisasi, Otonomi Daerah.}

\section{A. Pendahuluan}

Pasal 1 ayat (3) Undang-Undang Dasar (UUD) 1945 pasca perubahan dalam telah menegaskan bahwa Indonesia adalah negara hukum. Konsekuensi suatu negara hukum adalah menempatkan hukum di posisi teratas dalam meengelola segala kehidupan bernegara dan bermasyarakat. Hukum berada di atas segala-segalanya, negara, kekuasaan dan penguasapun tunduk kepada hukum.

Karena itu jika kemudian pasal 1 ayat (2) ) mengatur bahwa Kedaulatan berada di tangan rakyat dan dilaksanakan menurut Undang-Undang Dasar, menunjukkan adanya sebuah sebuah penegasan bahwa segala hukum dan kekuasaan negara dalam segala serba-serbinya haruslah mengabdi demi kepentingan rakyat. Termasuk di sini adalah upaya untuk mewujudkan kedaulatan rakyat tersebut melalui Pembentukan lembaga legislatif yakni Dewan Perwakilan Daerah (DPD) dan Dewan Perwakilan Rakyat (DPR) semestinya semaksimal mungkin demi rakyat. 
UUD 1945 dan UU tentang MPR, DPR, DPD dan DPRD telah mengatur Tugas dan wewenang ke dua lembaga legislatif tersebut yang terkait dengan fungsi legislasi dan fungsi lainnya. DPR mempunyai fungsi legislasi dalam semua bidang, sedangkan DPD terbatas hanya mengenai yang berkaitan dengan otonomi daerah, hubungan pusat dan daerah, pembentukan dan pemekaran serta penggabungan daerah, pengelolaan sumber daya alam dan sumber daya ekonomi lainnya, serta yang berkaitan dengan perimbangan keuangan pusat dan daerah.

\section{B. Pembahasan}

\section{Dasar Pengaturan}

Di Era Reformasi, wacana mengenai sistem dua kamar parlemen (bicameral system) yang lazim menjadi format parlemen pada banyak negara demokrasi, dalam UUD 1945 pasca amandemen diterjemahkan dengan membentuk DPD, sebagaimana dilembagakan berdasarkan Bab VII A Pasal $22 \mathrm{C}$ dan $22 \mathrm{D}$. Banyak pengamat masih mempertanyakan proses "adopsi kurang sempurna" sistem dua kamar tersebut (yaitu dengan dibentuknya DPR dan DPD) dalam UUD 1945, karena ternyata justru memunculkan sistem tiga kamar (tricameral) parlemen, yang tidak ada padanannya di negara demokrasi mana pun (yaitu, DPD, DPR dan MPR). ${ }^{1}$

DPD adalah sebuah lembaga perwakilan seperti halnya DPR yang mewakili masyarakat pada wilayah tertentu. Seluruh anggota MPR yang sekarang adalah hasil Pemilu. DPD merupakan alternatif baru bagi bentuk "utusan daerah" di MPR, yang lebih merepresentasikan kepentingan daerah. Bila pada MPR sistem yang lama anggota utusan daerah merupakan hasil pemilihan eksklusif anggota DPRD Propinsi, maka anggota DPD dipilih melalui Pemilu melalui sistem distrik berwakil banyak. Dalam sistem ini, masyarakat langsung memilih nama kandidat, yang memang disyaratkan untuk independen (bukan pengurus Partai Politik). Diharapkan dengan adanya "utusan daerah" model baru yang diwujudkan dalam lembaga DPD dengan sistem rekruitmen yang merupakan hasil pilihan rakyat melalui pemilu ini, dapat menjadi jembatan bagi aspirasi masyarakat daerah dalam pembuatan kebijakan pada tingkat nasional. $^{2}$

Dasar hukum yang mengatur tentang DPD, pertama kali muncul dalam UUD 1945 hasil perubahan ketiga, yaitu dalam pasal 2 ayat (1), seluruh pasal $22 \mathrm{C}$ dan pasal $22 \mathrm{D}$ serta pasal $22 \mathrm{E}$, pasal 23 ayat (2), pasal $23 \mathrm{E}$ ayat (2), pasal $23 \mathrm{~F}$ ayat (1), yang menampakkan bahwa pengaturannya dilakukan setelah pengaturan tentang kewenangan legislasi DPR dan presiden diselesaikan pada perubahan kedua terhadap UUD 1945.

Ketentuan dalam UUD 1945 tersebut ditindak lanjuti dengan Undang-Undang Nomor 22 Tahun 2003 tentang Susunan dan Kedudukan Majelis Permusyawaratan Rakyat, Dewan Perwakilan Rakyat, Dewan Perwakilan Daerah, dan Dewan Perwakilan Rakyat Daerah

\footnotetext{
W Riawan Tjandra, dalam http://www.yipd.or.id, acces 28 Januari 2009.

Http://www.scribd.com, 11 Nopember 2010
} 
(Lembaran Negara Republik Indonesia Tahun 2003 Nomor 92, Tambahan Lembaran Negara Republik Indonesia Nomor 4310), yang kemudian dicabut dan dinyatakan tidak berlaku dengan Undang-Undang Republik Indonesia Nomor 27 Tahun 2009 Tentang Majelis Permusyawaratan Rakyat, Dewan Perwakilan Rakyat, Dewan Perwakilan Daerah, Dan Dewan Perwakilan Rakyat Daerah (Lembaran Negara Republik Indonesia Tahun 2009 Nomor 123, Tambahan Lembaran Negara Republik Indonesia Nomor 5043).

\section{Tugas dan wewenang DPD}

Pengaturan tentang kewenangan DPR dalam Bab XIX UUD 1945 khususnya yang terdapat dalam pasal 20 A ayat (1) UUD 1945 adalah terkait dengan fungsi legislasi, fungsi penyusunan anggaran serta fungsi pengawasan atas pelaksanaan undang-undang dan penyelenggaraan pemerintahan negara. Sedangkan kewenangan DPD dalam Pasal 22 D UUD 1945 pada intinya meliputi tiga aspek. (1) Dapat mengajukan RUU kepada DPR. (2) Ikut membahas RUU. (3) Melakukan pengawasan atas pelaksanaan undang-undang. Ke tiga aspek kewenangan tersebut pada umumnya dikaitkan dengan perspektif otonomi daerah dan desentralisasi kekuasaan pemerintahan, termasuk pengelolaan sumber daya alam di daerah, ditambah pendidikan, agama dan perpajakan.

Dewan Perwakilan Daerah (DPD) merupakan amanat amandemen ketiga terhadap UUD 1945, dimana UUD 1945 telah mengatur sebagai berikut:

\section{Pasal 22C}

(1) Anggota Dewan Perwakilan Daerah dipilih dari setiap provinsi melalui pemilihan umum.***)

(2) Anggota Dewan Perwakilan Daerah dari setiap provinsi jumlahnya sama dan jumlah seluruh anggota Dewan Perwakilan Daerah itu tidak lebih dari sepertiga jumlah anggota Dewan Perwakilan Rakyat. ***)

(3) Dewan Perwakilan Daerah bersidang sedikitnya sekali dalam setahun. ***)

(4) Susunan dan kedudukan Dewan Perwakilan Daerah diatur dengan undang-undang ***)

\section{Pasal 22D}

(1) Dewan Perwakilan Daerah dapat mengajukan kepada Dewan Perwakilan Rakyat rancangan undang-undang yang berkaitan dengan otonomi daerah, hubungan pusat dan daerah, pembentukan dan pemekaran serta penggabungan daerah, pengelolaan sumber daya alam dan sumber daya ekonomi lainnya, serta yang berkaitan dengan perimbangan keuangan pusat dan daerah. ***)

(2) Dewan Perwakilan Daerah ikut membahas rancangan undang-undang yang berkaitan dengan otonomi daerah; hubungan pusat dan daerah; pembentukan, pemekaran, dan penggabungan daerah; pengelolaan sumber daya alam dan sumber daya ekonomi lainnya, serta perimbangan keuangan pusat dan daerah; serta memberikan pertimbangan kepada Dewan Perwakilan Rakyat atas rancangan undang-undang anggaran pendapatan dan belanja negara dan rancangan undangundang yang berkaitan dengan pajak, pendidikan, dan agama. $* * *)$ 
(3) Dewan Perwakilan Daerah dapat melakukan pengawasan atas pelaksanaan undangundang mengenai: otonomi daerah, pembentukan, pemekaran dan penggabungan daerah, hubungan pusat dan daerah, pengelolaan sumber daya alam dan sumber daya ekonomi lainnya, pelaksanaan anggaran pendapatan dan belanja negara, pajak, pendidikan, dan agama serta menyampaikan hasil pengawasannya itu kepada Dewan Perwakilan Rakyat sebagai bahan pertimbangan untuk ditindaklanjuti. ***)

(4) Anggota Dewan Perwakilan Daerah dapat diberhentikan dari jabatannya, yang syaratsyarat dan tata caranya diatur dalam undang-undang. $* * *$ )

Ketentuan tersebut kemudian diatur lebih lanjut dalam Pasal 224 UU No. 27 tahun 2009 tentang MPR, DPR, DPD dan DPRD, yang menegaskan bahwa:

(1) DPD mempunyai tugas dan wewenang:

a. dapat mengajukan kepada DPR rancangan undang-undang yang berkaitan dengan otonomi daerah, hubungan pusat dan daerah, pembentukan dan pemekaran serta penggabungan daerah, pengelolaan sumber daya alam dan sumber daya ekonomi lainnya, serta yang berkaitan dengan perimbangan keuangan pusat dan daerah;

b. ikut membahas bersama DPR dan Presiden rancangan undang-undang yang berkaitan dengan hal sebagaimana dimaksud dalam huruf a;

c. ikut membahas bersama DPR dan Presiden rancangan undang-undang yang diajukan oleh Presiden atau DPR, yang berkaitan dengan hal sebagaimana dimaksud dalam huruf a;

d. memberikan pertimbangan kepada DPR atas rancangan undang-undang tentang APBN dan rancangan undang-undang yang berkaitan dengan pajak, pendidikan, dan agama;

e. dapat melakukan pengawasan atas pelaksanaan undang-undang mengenai otonomi daerah, pembentukan, pemekaran, dan penggabungan daerah, hubungan pusat dan daerah, pengelolaan sumber daya alam, dan sumber daya ekonomi lainnya, pelaksanaan APBN, pajak, pendidikan, dan agama;

f. menyampaikan hasil pengawasan atas pelaksanaan undang-undang mengenai otonomi daerah, pembentukan, pemekaran, dan penggabungan daerah, hubungan pusat dan daerah, pengelolaan sumber daya alam dan sumber daya ekonomi lainnya, pelaksanaan undang-undang APBN, pajak, pendidikan, dan agama kepada DPR sebagai bahan pertimbangan untuk ditindaklanjuti;

g. menerima hasil pemeriksaan atas keuangan Negara dari BPK sebagai bahan membuat pertimbangan kepada DPR tentang rancangan undang-undang yang berkaitan dengan APBN;

h. memberikan memberikan pertimbangan kepada DPR dalam pemilihan anggota BPK; dan

i. ikut serta dalam penyusunan program legislasi nasional yang berkaitan dengan otonomi daerah, hubungan pusat dan daerah, pembentukan dan pemekaran serta penggabungan daerah, pengelolaan sumber daya alam dan sumber daya ekonomi lainnya, serta yang berkaitan dengan perimbangan keuangan pusat dan daerah. 
(2) Dalam menjalankan tugas pengawasan sebagaimana dimaksud pada ayat (1) huruf e, anggota DPD dapat melakukan rapat dengan pemerintah daerah, DPRD, dan unsur masyarakat di daerah pemilihannya.

Sebelumnya, pasal 41 UU No 22 Tahun 2003 tentang Susduk, telah membagi fungsi DPD atas dua macam: (1) Pengajuan usul, ikut dalam pembahasan dan memberikan pertimbangan yang berkaitan dengan bidang legislasi tertentu. (2) Pengawasan atas pelaksanaan UU tertentu. Telah disempurnakan dengan ketentuan Pasal 223 UU No 27 tahun $2009^{3}$. menjadi 4 macam fungsi DPD yaitu:

a. Pengajuan usul kepada DPR mengenai rancangan undang-undang yang berkaitan dengan otonomi daerah, hubungan pusat dan daerah, pembentukan dan pemekaran serta penggabungan daerah, pengelolaan sumber daya alam dan sumber daya ekonomi lainnya, serta yang berkaitan dengan perimbangan keuangan pusat dan daerah;

b. ikut dalam pembahasan rancangan undang-undang yang berkaitan dengan otonomi daerah, hubungan pusat dan daerah, pembentukan, pemekaran dan penggabungan daerah, pengelolaan sumber daya alam dan sumber daya ekonomi lainnya, serta perimbangan keuangan pusat dan daerah;

c. pemberian pertimbangan kepada DPR atas rancangan undang-undang tentang anggaran pendapatan dan belanja negara dan rancangan undang-undang yang berkaitan dengan pajak, pendidikan, dan agama; dan

d. pengawasan atas pelaksanaan undang-undang mengenai otonomi daerah, pembentukan, pemekaran dan penggabungan daerah, hubungan pusat dan daerah, pengelolaan sumber daya alam dan sumber daya ekonomi lainnya, pelaksanaan APBN, pajak, pendidikan, dan agama.

Skema kewenangan dan fungsi DPD tersebut masih memperlihatkan secara transparan subordinasi kedudukan dan peranan DPD dalam proses pengambilan kebijakan di parlemen. Ruang otonomi daerah yang telah menggeser pendulum kekuasaan pada parlemen daerah telah membangun sistem parlemen daerah yang nyaris memiliki kekuasaan mutlak di daerah. Realitas tersebut dapat menyebabkan kedudukan DPD "mengambang" di antara dua kekuasaan, yaitu kekuasaan parlemen pusat (DPR) dan parlemen daerah (DPRD). Hal ini disebabkan dalam proses pengambilan kebijakan parlemen, DPD masih diperankan secara marjinal. Ruang kewenangannya tidak lebih hanya untuk "mengusulkan", "turut membahas" dan "dapat melakukan pengawasan". ${ }^{4}$

Usul RUU dari DPD disalurkan kepada DPR, dan kewenangan untuk menetapkan RUU tersebut tetap berada pada persetujuan bersama antara DPR dan presiden. Dahulu, Pasal 42

3 UU No. 27 Tahun 2009 Tentang MPR, DPR , DPD dan DPRD adalah UU yang menggantikan UndangUndang Nomor 22 Tahun 2003 tentang Susunan dan Kedudukan Majelis Permusyawaratan Rakyat, Dewan Perwakilan Rakyat, Dewan Perwakilan Daerah, dan Dewan Perwakilan Rakyat Daerah (Lembaran Negara Republik Indonesia Tahun 2003 Nomor 92, Tambahan Lembaran Negara Republik Indonesia Nomor 4310).

4 Http://www.scribd.com. Op.cit. 
ayat (3) UU Susduk bahkan menyatakan bahwa pembahasan RUU yang diusulkan oleh DPD tersebut dilakukan sebelum DPR membahas RUU tersebut dengan Pemerintah. Hal ini justru terkesan DPD diberikan posisi sebagai the outsider dalam mekanisme pembahasan RUU. ${ }^{5}$ Walaupun dalam UU No. 27 tahun 2009 yang menggantikan UU Susduk tersebut, dalam Pasal 150 ayat (1) dan (2) UU No 27 tahun 2009 telah memberikan perluasan kewenangan kepada DPD. ${ }^{6}$

Membaca rumusan ketentuan tersebut segera diperoleh gambaran bahwa pada hakikatnya DPD tidak memiliki bentuk kewenangan efektif terhadap pembuatan dan pengawasan atas pelaksanaan undang-undang. Sangat mudah hasil pengawasan DPD mengalami distorsi dalam penerapannya, mengingat kedudukan hasil pengawasan tersebut tidak lebih hanya sebagai "bahan pertimbangan" bukan sebagai rekomendasi politik yang dapat memaksa tindakan lanjutan sehubungan dengan hasil temuan pengawasan oleh DPD. ${ }^{7}$

Fenomena ini sangat mudah memunculkan penilaian bahwa eksistensi DPD hanya dijadikan aksesori demokrasi parlemen. Bias kewenangan MPR dalam format konstitusi turut menjadi argumen yang kuat atas penilaian mengenai eksistensi DPD dalam parlemen. ${ }^{8}$

\section{Asas Desentralisasi dan Sistem Otonomi Daerah}

Negara Kesatuan Republik Indonesia dibagi atas daerah-daerah provinsi. Daerah provinsi itu dibagi lagi atas daerah kabupaten dan daerah kota. Setiap daerah provinsi, daerah kabupaten, dan daerah kota mempunyai pemerintahan daerah yang diatur dengan undangundang. Pemerintahan daerah provinsi, daerah kabupaten, dan kota mengatur dan mengurus sendiri urusan pemerintahan menurut asas otonomi dan tugas pembantuan. ${ }^{9}$ Hingga bulan Agustus 2008, setidaknya Indonesia telah memiliki 501 daerah otonom, yang terdiri dari 33 propinsi, 386 kabupaten dan 91 kota. ${ }^{10}$

Pemerintah pusat adalah Presiden Republik Indonesia yang memegang kekuasaan pemerintahan negara Republik Indonesia sebagaimana dimaksud dalam Undang-Undang Dasar Negara Republik Indonesia Tahun 1945.

Sedangkan yang dimaksud dengan Pemerintahan daerah adalah penyelenggaraan urusan pemerintahan oleh pemerintah daerah dan DPRD menurut asas otonomi dan tugas

\footnotetext{
W Riawan Tjandra, Op.cit.

6 Lihat Pasal 150 ayat (1) dan (2) UU No 27 tahun 2009 mengenai Pembicaraan Tingkat I dalam sesi pengantar musyawarah, Pada point yang memberikan perluasan kewenangan kepada DPD:

a. DPR memberikan penjelasan serta Presiden dan DPD menyampaikan pandangan apabila rancangan undang-undang yang berkaitan dengan kewenangan DPD sebagaimana dimaksud dalam Pasal 71 huruf e berasal dari DPR; atau

b. Presiden memberikan penjelasan serta fraksi dan DPD menyampaikan pandangan apabila rancangan undang-undang yang berkaitan dengan kewenangan DPD sebagaimana dimaksud dalam Pasal 71 huruf e berasal dari Presiden. 
pembantuan $^{11}$ dengan prinsip otonomi seluas-luasnya dalam sistem dan prinsip Negara Kesatuan Republik Indonesia sebagaimana dimaksud dalam Undang-Undang Dasar Negara Republik Indonesia Tahun 1945. Termasuk Pemerintah daerah adalah Gubernur, Bupati, atau Walikota, dan perangkat daerah sebagai unsur penyelenggara pemerintahan daerah. ${ }^{12}$

Perundang-undangan yang mengatur tentang daerah tersebut dapat diketahui telah ada sejak tahun awal kemerdekaan RI, antara lain: ${ }^{13}$
a. UU Nomor 1 Tahun 1945
b. UU Nomor 22 Tahun 1948
c. UU Nomor 44 Tahun 1950
d. UU Nomor 1 Tahun 1957
e. UU Nomor 6 Tahun 1959
f. UU Nomor 5 Tahun 1960
g. UU Nomor 18 Tahun 1965
h. UU Nomor 5 Tahun 1974
i. $\quad$ UU Nomor 22 Tahun 1999
j. UU Nomor 18 Tahun 2001
k. UU Nomor 32 Tahun 2004
1. UU Nomor 8 Tahun 2005
m. UU Nomor 11 Tahun 2006
n. UU Nomor 12 Tahun 2008.

Pemerintahan daerah dalam menyelenggarakan urusan pemerintahan memiliki hubungan dengan pemerintah pusat dan dengan pemerintahan daerah lainnya. ${ }^{14}$ Hubungan tersebut secara umum meliputi hubungan wewenang, keuangan, pelayanan umum, pemanfaatan sumber daya alam, dan sumber daya lainnya. Hubungan keuangan, pelayanan umum, pemanfaatan sumber daya alam, dan sumber daya lainnya dilaksanakan secara adil dan selaras. Hubungan wewenang, keuangan, pelayanan umum, pemanfaatan sumber daya alam dan sumber daya lainnya menimbulkan hubungan administrasi dan kewilayahan antar susunan pemerintahan, yang meliputi 16 urusan.

Sementara kewenangan yang menjadi kewenangan Pemerintah pusat (Residu power) adalah bidang politik luar negeri, pertahanan, keamanan, yustisi, moneter dan fiskal nasional, dan agama ${ }^{15}$. Ketentuan yang mengatur hal tersebut antara lain:

11 Penjelasan atas pasal 2 Ayat (2) UU No. 32 tahun 2004 menyatakan, Yang dimaksud dengan asas otonomi dan tugas pembantuan dalam ayat ini adalah bahwa pelaksanaan urusan pemerintahan oleh daerah dapat diselenggarakan secara langsung oleh pemerintahan daerah itu sendiri dan dapat pula penugasan oleh pemerintah provinsi ke pemerintah kabupaten/kota dan desa atau penugasan dari pemerintah kabupaten/kota ke desa.

12 Lihat pasal langka 1, 2, 3 UU No. 32 Tahun 2004 Tentang Pemerintahan Daerah.

$13 \mathrm{http}: / /$ medizton.wordpress.com, acces 15 Mei 2010.

14 Ibid.

15 Salah satu perubahan besar dalam hubungan pusat dan daerah sejak adanya Perundang-undangan Pemerintahan Daerah adalah dianutnya prinsip residu power (pembagian kewenangan sisa) dalam penataan 
a. Pasal 7 Ayat (1) Dalam UU No 22/1999 Tentang tentang Pemerintahan Daerah, menyatakan bahwa "kewenangan daerah otonom mencakup kewenangan dalam seluruh bidang pemerintahan, kecuali kewenangan dalam bidang politik luar negeri, pertahanan keamanan, peradilan, moneter dan fiskal, agama, serta kewenangan bidang lain".

b. Pasal 10 Ayat (1) UU No. 32 Tahun 2004 tentang Pemerintahan Daerah, menyatakan bahwa "pemerintahan daerah menyelenggarakan urusan pemerintahan yang menjadi kewenangannya, kecuali urusan pemerintahan yang oleh UndangUndang ini (baca: UU No 32/2004) ditentukan menjadi urusan Pemerintah”.

c. Pasal 10 Ayat (2) UU No 32/2004 tentang Pemerintahan Daerah, menyatakan bahwa "urusan pemerintahan yang menjadi urusan Pemerintah sebagaimana dimaksud pada Ayat (1) meliputi: (a) politik luar negeri; (b) pertahanan; (c) keamanan; (d) yustisi; (e) moneter dan fiskal nasional; dan (f) agama".

Sementara Pengertian "otonom" secara bahasa adalah "berdiri sendiri” atau "dengan pemerintahan sendiri". Sedangkan "daerah" adalah suatu "wilayah" atau "lingkungan pemerintah". Dengan demikian pengertian secara istilah "otonomi daerah" adalah "wewenang/kekuasaan pada suatu wilayah/daerah yang mengatur dan mengelola untuk kepentingan wilayah/daerah masyarakat itu sendiri." Pengertian yang lebih luas lagi adalah wewenang/kekuasaan pada suatu wilayah/daerah yang mengatur dan mengelola untuk kepentingan wilayah/daerah masyarakat itu sendiri mulai dari ekonomi, politik, dan pengaturan perimbangan keuangan termasuk pengaturan sosial, budaya, dan ideologi yang sesuai dengan tradisi adat istiadat daerah lingkungannya. ${ }^{16}$

Jadi pemerintah daerah propinsi, kabupaten/ kota adalah pengelola dari daerah otonom. Yang dimaksud dengan daerah otonom adalah yaitu kesatuan masyarakat hukum yang mempunyai batas-batas wilayah yang berwenang mengatur dan mengurus urusan pemerintahan dan kepentingan masyarakat setempat menurut prakarsa sendiri berdasarkan aspirasi masyarakat dalam sistem Negara Kesatuan Republik Indonesia. ${ }^{17}$

Pengelolaan daerah otonom dalam pelaksanaannya bertitik tolak dari otonomi daerah yang dimilikinya yang mencakup hak, wewenang, dan kewajiban daerah otonom untuk mengatur dan mengurus sendiri urusan pemerintahan dan kepentingan masyarakat setempat sesuai dengan peraturan perundang-undangan. ${ }^{18}$

Dasar pemikiran yang melatarbelakangi adanya otonomi daerah adalah keinginan untuk memindahkan pengambilan keputusan untuk lebih dekat dengan mereka yang merasakan langsung pengaruh program dan pelayanan yang dirancang dan dilaksanakan oleh pemerintah. Hal ini akan meningkatkan relevansi antara pelayanan umum dengan kebutuhan dan kondisi

hubungan pusat-daerah misalnya Pasal 7 Ayat (1) UU No 22/1999 dan Pasal 10 Ayat (1) Undang-Undang Nomor 32 Tahun 2004 tersebut. http://www.saldiisra.web.id. Acces 23 Desember 2010.

16 Http://www.Wikipedia.co.id, akses 24 Nopember 2009.

17 Lihat pasal langka 6 UU No. 32 Tahun 2004 Tentang Pemerintahan Daerah.

18 Lihat pasal langka 5 UU No. 32 Tahun 2004 Tentang Pemerintahan Daerah. 
masyarakat lokal, sekaligus tetap mengejar tujuan yang ingin dicapai oleh pemerintah ditingkat daerah dan nasional, dari segi sosial dan ekonomi.

Dalam pelaksanaan otonomi daerah, ada beberapa asas pemerintahan di daerah yang diterapkan. Secara teoritis dapat diketahui asas-asas untuk menyelenggarakan pemerintahan daerah, pada dasarnya ada 4 (empat), yaitu:

a. Sentralisasi yaitu sistem pemerintahan di mana segala kekuasaan dipusatkan di pemerintah pusat.

b. Desentralisasi yaitu penyerahan wewenang pemerintahan oleh pemerintah kepada daerah otonom untuk mengatur dan mengurus urusan pemerintahan dalam sistem Negara Kesatuan Republik Indonesia.

c. Dekonsentrasi yaitu pelimpahan wewenang pemerintahan oleh pemerintah kepada gubernur sebagai wakil pemerintah dan/atau kepada instansi vertikal di wilayah tertentu.

d. Tugas Pembantuan yaitu penugasan dari pemerintah kepada daerah dan/atau desa, dari pemerintah propinsi kepada kabupaten/kota dan/atau desa, dari pemerintah kabupaten/kota kepada desa untuk melaksanakan tugas tertentu. ${ }^{19}$

Lahirnya konsep desentralisasi merupakan upaya untuk mewujudkan seuatu pemerintahan yang demokratis dan mengakhiri pemerintahan yang sentralistik. Pemerintahan sentralistik menjadi tidak populer karena telah dinilai tidak mampu memahami dan memberikan penilaian yang tepat atas nilai-nilai yang hidup dan berkembang di daerah.

Desentralisasi adalah pembentukan daerah otonom dengan kekuasaan kekuasaan tertentu dan bidang-bidang kegiatan tertentu yang diselenggarakan berdasarkan pertimbangan, inisiatif, dan administrasi sendiri, sehingga akan dijumpai proses pembentukan daerah yang berhak mengatur kepentingan daerahnya. ${ }^{20}$

Untuk itu perlu diketengahkan kiranya pendapat dari Syaukani, yang menyatakan pada dasarnya tujuan penyelenggaraan desentralisasi antara lain :

a. Dalam rangka peningkatan efesiensi dan efektivitas penyelenggaraan pemerintahan.

b. sebagai wahana pendidikan politik masyarakat di daerah.

c. dalam rangka memelihara keutuhan negara kesatuan atau integrasi nasional.

d. untuk mewujudkan demokrasi dalam penyelenggaraan pemerintahan yang dimulai dari daerah.

e. guna memberikan peluang bagi masyarakat untuk membentuk karir dalam bidang politik dan pemerintahan.

f. sebagai wahana yang diperlukan untuk memberikan peluang bagi masyarakat untuk berpartisipasi dalam proses perencanaan dan pelaksanaan pemerintahan.

g. sebagai sarana yang diperlukan untuk mempercepat pembangunan di daerah.

19 Lihat pasal 1angka 7, 8, 9 UU No. 32 Tahun 2004 Tentang Pemerintahan Daerah.

20 Ibid. 
h. guna mewujudkan pemerintahan yang bersih dan berwibawa. ${ }^{21}$

Menurut Samodra Wibawa Ada beberapa alasan perlunya pemerintah pusat mendesentralisasikan kekuasaan kepada pemerintah daerah, yaitu:

a. segi politik, desentralisasi dimaksudkan untuk mengikutsertakan warga dalam proses kebijakan, baik untuk kepentingan daerah sendiri maupun untuk mendukung politik dan kebijakan nasional melalui pembangunan proses demokrasi di lapisan bawah.

b. segi manajemen pemerintahan, desentralisasi dapat meningkatkan efektivitas, efisiensi, dan akuntabilitas publik terutama dalam penyediaan pelayanan publik.

c. segi kultural, desentralisasi untuk memperhatikan kekhususan, keistimewaan suatu daerah, seperti geografis, kondisi penduduk, perekonomian, kebudayaan, atau latar belakang sejarahnya.

d. segi kepentingan pemerintah pusat, desentralisasi dapat mengatasi kelemahan pemerintah pusat dalam mengawasi program-programnya.

e. segi percepatan pembangunan, desentralisasi dapat meningkatkan persaingan positif antar daerah dalam memberikan pelayanan kepada masyarakat sehingga mendorong pemerintah daerah untuk melakukan inovasi dalam rangka meningkatkan kualitas pelayanan kepada masyarakat. ${ }^{22}$

Menurut The Liang Gie dikutip oleh Muhammad Fauzan, desentralisasi dalam penyelenggaraan pemerintahan daerah didasarkan pada : ${ }^{\mathbf{2 3}}$

a. dilihat dari sudut politik, desentralisasi dimaksudkan untuk mencegah penumpukan kekuasaan pada satu pihak saja yang apda akhirnya dapat menimbulkan tirani.

b. penyelenggaraan desentralisasi dianggap sebagai pendemokrasian, untuk menarik rakyat ikut serta dalam pemerintahan dan melatih diri dalam menggunakan hak-hak demokrasi.

c. dari sudut teknis organisatoris pemerintahan, desentralisasi adalah untuk mencapai suatu pemerintahan yang efesien.

$$
\begin{array}{ll} 
& \\
& \text { Ibid. } \\
\text { Ibid. } \\
\text { Ibid }
\end{array}
$$


Krishna D. Darumurti dan Umbu Rauta mengetengahkan Kelebihan dan Kelemahan Desentralisasi dengan mengutip pendapat Josef Riwu Kaho, Kelebihan desentralisasi yaitu:

a. mengurangi bertumpuknya pekerjaan di pusat pemerintahan.

b. dalam menghadapi masalah yang mendesak yang membutuhkan tindakan yang cepat, daerah tidak perlu menunggu instruksi lagi dari pemerintah pusat.

c. dapat mengurangi birokrasi dalam arti buruk karena setiap kebutusan dapat segera dilaksanakan.

d. mengurangi kemungkinan kesewenang wenangan dari pemerintah pusat.

e. dapat memberikan kepuasan bagi daerah karena sifatnya lebih langsung. ${ }^{24}$

Kelemahan desentralisasi :

a. Karena besarnya organ-organ pemerintah, maka struktur pemerintahan bertambah kompleks yang mempersulit koordinasi.

b. keseimbangan dan keserasian antara bermacam-macam kepentingan dan daerah dapat lebih mudah terganggu.

c. dapat mendorong timbulnya fanatisme daerah.

d. keputusan yang diambil memerlukan waktu yang lama.

e. diperlukan biaya yang lebih banyak. ${ }^{25}$

Muhammad Fauzan mengetengahkan pendapat bahwa konsep desentralisasi mengandung beberapa kebaikan dengan mengutip pendapat J. In het Veld, yaitu :

a. memberikan penilaian yang tepat terhadap daerah dan penduduk yang beraneka ragam.

b. meringankan beban pemerintah, karena pemerintah pusat tidak mungkin mengenal seluruh dan segala kepentingan dan kebutuhan setempat dan tidak mungkin dapat mengetahui bagaimana memenuhi kebutuhan tersebut sebaik-baiknya.

c. dapat dihindarkan adanya beban yang melampaui batas dari perangkat pusat oleh sebab tunggakan kerja.

d. unsur individu atau daerah lebih menonjol karena dalam ruang lingkup yang sempit seseorang dapat lebih mempergunakan pengaruhnya daripada dalam masyarakat yang lebih luas.

e. masyarakat setempat dapat kesempatan ikut serta dalam penyelenggaraan pemerintahan, sehingga ia tidak akan merasa sebagai obyek saja.

f. meningkatkan turut sertanya masyarakat setempat dalam melakukan kontrol terhadap segala tindakan dan tingkah laku pemerintah. ${ }^{26}$

\section{Mengkaji Pelaksanaan Peran DPD}

Sejarah istilah demokrasi sudah muncul pada tahun 431 SM, ketika Pericles, seorang

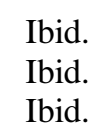


negarawan Athena, mendefinisikan demokrasi dengan beberapa kriteria sebagai berikut :

a. Pemerintahan oleh rakyat dengan partisipasi rakyat yang penuh dan langsung.

b. Kesamaan didepan hukum.

c. Pluralisme yaitu penghargaan atas semua bakat, minat, keinginan, dan pandangan.

d. Penghargaan terhadap suatu pemisahan dan wilayah pribadi. ${ }^{27}$

Perlu dipahami sistem politik demokratis adalah sistem yang menunjukkan bahwa kebijakan umum ditentukan atas dasar mayoritas oleh wakil-wakil yang diawasi secara efektif oleh rakyat dalam pemilihan-pemilihan berkala yang didasarkan atas prinsip kesamaan politik dan diselenggarakan dalam suasana terjaminnya kebebasan politik.

Dalam upaya untuk mewujudkan kedaulatan rakyat secara demokratis struktur ketatanegaraan yang diatur dalam UUD 1945 mengatur tiga lembaga utama dalam organ legislatif Indonesia, yaitu MPR, DPR dan DPD.

Sistem ketatanegaraan Indonesia telah menjadikan struktur MPR yang sebelumnya terdiri dari anggota DPR, utusan daerah dan utusan golongan, kini berubah wujud menjadi suatu lembaga yang terdiri dari anggota DPR dan anggota DPD. Utusan daerah dihapuskan dan diganti dalam bentuk DPD, sebuah "kamar kedua" yang dianggap lebih merepresentasikan "utusan daerah". Sementara Utusan Golongan yang keanggotaannya didapat melalui penunjukkan dari tiap golongan, ditiadakan karena representasinya yang tidak jelas dan dianggap sudah terwakili melalui Partai Politik (Parpol). ${ }^{28}$

Jika misalnya Perubahan struktur ketatanegaraan ini dalam rangka mengimplementasikan sistem perwakilan dua kamar (bicameral system) dengan adanya DPR dan DPD. Perlu dicatat bahwa Parlemen bikameral mengandung konsepsi dasar mengenai parlemen, ia seharusnya mempunyai tiga fungsi utama parlemen, yaitu legislatif, pengawasan, dan anggaran.

Ada dua model parlemen bikameral yang berkembang dalam praktek ketatanegaraan di dunia:

Pertama, model Westminster (bicameral Inggris), di mana lower house (house of commons) muncul sebagai evolusi untuk menyeimbangkan kedudukan parlemen di sana, yang pada awalnya hanya terdiri dari para bangsawan (house of lords). Semangat untuk memperkuat demokrasi perwakilan bagi semua rakyat menumbuhkan model ini.

Ke dua, model Consensus (bikameral Amerika Serikat) di mana kamar kedua muncul sebagai kompromi politik dalam pembentukan negara federal, di mana negaranegara bagian yang kecil menginginkan representasi yang lebih kuat dengan adanya kamar pertama yang mewakili wilayah dengan jumlah anggota yang sama

27 Catur Wido Haruni, dalam Laporan Penelitian "Kajian Kritis Terhadap Penyelesaian Sengketa Pemilihan Kepala Daerah Secara Langsung ditinjau dari UU No. 32 Tahun 2004 Tentang Pemerintahan Daerah”, DP2M UMM, 2009. hal 6.

28 Ibid. 
untuk tiap Negara bagian, tanpa memperhitungkan luas wilayah dan jumlah penduduknya. $^{29}$

Jika mengkaji lebih lanjut tentang Teori Bikameral, Maurice Duverger menyatakan ada 2 (dua) model, yaitu simetris dan asimetris. Model simetris, seperti yang berlaku di negaranegara federal dan yang menganut bikameral, mengandung pengertian bahwa antar kamar memiliki kedudukan yang simetris. Sebagai contoh, Jepang. Indonesia dan Jepang memiliki kesamaan dalam hal bentuk Negara, yakni sama-sama Negara kesatuan, ${ }^{30}$ menganut sistem bikameral, dan kedua kamar sama-sama dibentuk berdasarkan pemilu. Ini ditunjukkan dengan ketentuan Pasal 59 Konstitusi Jepang bahwa RUU harus mendapat persetujuan dari kedua kamar. Ini ada hubungannya dengan teori Rosseau mengenai kedaulatan rakyat, parlemen merupakan pemegang voluntee generale sehingga menurut konsepsi ini yang dimaksud dengan the people souvereignity, ${ }^{31}$ ini adalah parlemen. Artinya, antara kedua kamar mesti equal karena prinsipnya kedua kamar memiliki legitimasi yang sama yang diperoleh melalui pemilu.

Sejak awal, adanya tuntutan untuk bikameral didasarkan pada tiga tujuan:

a. Kebutuhan dalam pembenahan sistem ketatanegaraan yang berkaitan dengan supremasi MPR dan adanya anggota-anggota yang tidak dipilih dan tidak efektif (utusan golongan dan utusan daerah).

b. kebutuhan untuk mengakomodasikan masyarakat daerah secara struktural.

c. kebutuhan Indonesia saat ini untuk menerapkan sistem checks and balances dan mendorong demokratisasi.

29 Http://www.parlemen.net, acces 13 Desember 2010.

30 Ibid. Secara teoritis dikenal adanya dua model dalam formasi negara yaitu negara kesatuan dan negara federal. Bentuk negara federal adalah suatu bentuk yang lazim dianut oleh berbagai negara di dunia. Persepsi bahwa negara serikat akan menimbulkan perpecahan, disintegrasi bangsa, separatisme, tentu memerlukan analisis yang mendalam. Menurut C.F. Strong ciri-ciri negara kesatuan ialah kedaulatan tidak terbagi atau dengan perkataan lain kekuasaan pemerintah pusat tidak dibatasi, karena konstitusi negara kesatuan tidak mengakui adanya lembaga legislatif lain selain lembaga legislatif pusat. Menurutnya ada dua ciri yang mutlak yang melekat pada suatu negara kesatuan : Pertama, adanya supremasi dari pemerintah pusat, kedua, tidak adanya badan-badan lain yang berdaulat. Asumsi dasar model negara kesatuan berbeda dengan negara federal. Bentuk negara kesatuan dideklarasikan saat kemerdekaan oleh para pendiri negara dengan mengklaim seluruh wilayahnya sebagai bagian dari negara tersebut. Tidak ada kesepakatan dari para penguasa daerah apalagi negara-daerah, karena diasumsikan bahwa semua wilayah yang termasuk di dalamnya bukanlah bagian-bagian wilayah yang bersifat independen. Dengan dasar itu, maka negara membentuk daerah-daerah atau wilayah-wilayah yang kemudian diberi kekuasaan atau kewenangan oleh pemerintah pusat untuk mengurus berbagai kepentingan masyarakatnya. Dalam hal ini, negaralah yang menjadi sumber kekuasaan. Kekuasaan daerah pada dasarnya adalah kekuasaan pusat yang didesentralisasikan dan selanjutnya terbentuklah daerah-daerah otonom. Dapat dikatakan bahwa otonomi daerah adalah wujud pemberian kekuasaan oleh pemerintah pusat.

31 Ibid. Dalam perkembangannya lebih lanjut, mengenai kekuasaan yang tertinggi dalam negara menimbulkan bermacam pandangan atau teori tentang kedaulatan. Macam-macam teori tersebut menyatakan :

1) Kedaulatan tertinggi dalam negara itu adalah Tuhan (God souvereiniteit);

2) Kedaulatan tertinggi dalam negara itu adalah negara itu sendiri (Staats souvereiniteit);

3) Kedaulatan tertinggi dalam negara adalah hukum (Rechts souvereiniteit);

4) Kedaulatan tertinggi dalam negara adalah rakyat (Volks souvereiniteit). 
Ketiga tujuan ini tidak semuanya terpenuhi karena wewenang DPD yang terbatas dan MPR yang berkarateristik seperti diuraikan di atas. ${ }^{32}$

Dalam sistem desentralisasi, sebenarnya dibutuhkan adanya semacam "majelis rendah" dalam parlemen yang secara konkret dapat menjadi saluran aspirasi bagi daerah. Peran tersebut akan sulit diperankan oleh DPD selama setting kewenangan DPD masih berjalan menurut skenario Pasal 22 C dan D UUD 1945 dan Pasal 42 - 48 UU Susduk, yang menganut konsep peranan sempit bagi DPD. Seharusnya DPD berfungsi untuk secara optimal mewakili daerah secara keseluruhan dengan kewenangan yang substansial, bukan artifisial dalam legislasi dan controling, sedangkan kepentingan individu rakyat disalurkan melalui DPR, sehingga dapat terwujud hakikat check and balance kekuasaan pemerintahan. ${ }^{33}$

Ide dasar pembentukan DPD RI adalah terakomodasinya kepentingan daerah dalam pembentukan undang-undang. Anggota DPD RI adalah mewakili kepentingan daerah. Namun muncul persoalan DPD RI mewakili daerah secara keseluruhan ataukah setiap anggota DPD RI mewakili daerah tertentu. Karena daerah menurut UUD NRI 1945 itu adalah propinsi, kabupaten, dan kota yang masing-masing berhak mengatur rumah tangga sendiri, maka yang dimaksud mewakili daerah bisa ditafsir setiap daerah baik propinsi, kabupaten, dan kota mempunyai wakil yang sama, misalnya 1 orang. Dengan ketentuan seperti ini setiap anggota DPD RI baru jelas ia mewakili daerah yang mana. Sebaliknya setiap daerah akan jelas siapa yang mewakili kepentingannya. ${ }^{34}$

Dibentuknya DPD RI itu dimaksudkan untuk memperkuat ikatan daerah-daerah dalam wadah Negara Kesatuan Republik Indonesia (NKRI) dan memperteguh persatuan kebangsaan seluruh daerah-daerah. Juga untuk meningkatkan agregasi dan akomodasi aspirasi dan kepentingan daerah-daerah dalam perumusan kebijakan nasional berkaitan dengan negara dan daerah-daerah. Disamping itu untuk mendorong percepatan demokrasi, pembangunan dan kemajuan daerah-daerah secara serasi dan seimbang untuk mewujudkan kesejahteraan rakyat. Sementara pertimbangan teoritis dibentuknya DPD antara lain adalah untuk membangun mekanisme kontrol dan keseimbangan (check and balances) antar cabang kekuasaan negara dan antar lembaga legislatif sendiri. ${ }^{35}$

Manfaat lain dengan komposisi keanggotaan seperti ini, akan terdapat perimbangan kursi di MPR RI antara anggota DPR RI dan anggota DPD RI. Perimbangan ini sangat penting karena MPR RI memiliki kewenangan strategis utamanya berupa perubahan UUD dan pemberhentian Presiden. ${ }^{36}$

\footnotetext{
32 “Fungsi dan Peran Ideal Dewan Perwakilan Daerah” oleh Bivitri Susanti, dalam Http://www.pshk.or.id, acces 28 Jul 2005

33 W Riawan Tjandra, Op.cit.

34 Laporan Penelitian: "konstruksi perwakilan daerah dalam sistem ketatanegaraan indonesia", PKK Unibraw DPD RI, 2009.

35 A.M. Fatwa, "peran dpd dalam sistem ketatanegaraan Indonesia", dalam Http://www.thefatwacenter.com, acces 12 Nopember 2010

36 Laporan Penelitian: "konstruksi perwakilan daerah dalam sistem ketatanegaraan indonesia", PKK Unibraw DPD RI, 2009.
} 
Ciri utama sistem presidensiil adalah memisahkan kekuasaan eksekutif dan legislatif. Eksekutif relatif independen dari legislatif. Dalam sistem UUD NRI 1945, manifestasi independensi eksekutif dari legislatif diwujudkan melalui pemilihan umum yang diselenggarakan secara langsung dan terpisah antara eksekutif (Presiden RI) dan anggota legislatif (DPR RI dan DPD). Karena ciri ini, Undang-Undang Dasar harus diselaraskan kembali untuk memisahkan fungsi eksekutif menjalankan pemerintahan dan fungsi legislatif sebagai pembentuk undang-undang. Sedangkan fungsi legislatif diselenggarakan secara berimbang dua kamar DPR RI dan DPD RI yang anggotanya telah dipilih secara langsung. Adanya DPD RI akan meningkatkan posisi tawar daerah dalam memperjuangkan aspirasi daerah secara langsung di tingkat pusat. Ini artinya DPD RI disebut sebagai salah satu chamber legislatif. ${ }^{37}$

Sewaktu DPD pertama kali digaungkan oleh kalangan akademisi dan Ornop, DPD diharapkan dapat mewakili wilayah-wilayah di Indonesia dan bertugas sebagai mitra tanding yang sejajar dengan DPR. Namun konsep ini kembali diadopsi setengahnya dan dicampur dengan kepentingan politik saat amandemen UUD tahun 2001 dilakukan. Usulan mengenai DPD diterima, namun posisi yang sejajar dengan DPR tidak diberikan. Kewenangan dan kedudukannya sangat jauh dari yang diharapkan. ${ }^{38}$

Jika Anggota DPR dipertalikan oleh benang merah sebagai unsur partainya yang memang menyebar diseluruh Republik Indonesia. Anggota DPR disamping dinilai oleh rakyat pemilihnya maka riwayatnya sangat ditentukan oleh penilaian partainya. Maka Yang menghubungkan anggota DPD adalah tanggungjawab kebangsaan dan langgengnya NKRI. Selebihnya dia dituntut all out untuk kepentingan daerah dan konstituennya yaitu rakyat di daerah asalnya. ${ }^{39}$

Namun pengejawantahan peran DPD dalam memperjuangkan kepentingan daerah menghadapi kendala, karena Makna otonomi daerah seharusnya memberikan otonomi rakyat daerah dalam berhadapan dengan birokrasi pemerintahan secara keseluruhan. Terlihat adanya kecenderungan bias tafsir makna otonomi daerah tersebut menjadi pemberian kewenangan yang lebih besar kepada pemerintah daerah, yang menunjukkan adanya penyempitan makna kebijakan otonomi daerah hanya menjadi otonomi pemerintah daerah. ${ }^{40}$

Seharusnya restrukturisasi dan rekontruksi lembaga perwakilan, hendaknya memperjelas jenis parlemen dalam tipologi unikameral atau bikameral. Tetapi restrukturisasi dan rekonstruksi dalam lembaga perwakilan ini sudah bermasalah sejak awal karena yang dihasilkan adalah hubungan lembaga perwakilan yang asimetrik. Watak asimetrik tersebut dapat dilihat dari sistem pemilihan, jumlah anggota, wewenang masing-masing lembaga (jika tidak dapat disebut sebagai "kamar"), mekanisme pengambilan putusan dan hubungan interkameral pada umumnya.

37 Ibid.

38 Bivitri Susanti, Op Cit.

39 Soemardhi Thaher, “DPD Mau Kemana?”, dalam Http://digilib.umm.ac.id

40 W Riawan Tjandra, Op.cit. 
Akibatnya, pelembagaan perwakilan wilayah (spatial representation), baik pada tingkat konstitusi maupun dalam teknis hubungan antarlembaga seperti halnya dalam proses legislasi, tidak tergambar secara jelas watak keterwakilan daerah. ${ }^{41}$

Mengenai lembaga perwakilan di Indonesia, menarik komentar yang dikemukakan oleh Prof. Rusadi Kantaprawira yang menyatakan: ${ }^{\mathbf{4 2}}$

"Bagaimanapun harus diperhatikan oleh Indonesia bahwa Indonesia punya sejarah kecuali yang dibuat oleh van Mook dengan konsep Republik Indonesia Serikat. Saya sendiri tidak berani mengatakan bahwa itu adalah ide dari van Mook karena bisa jadi itu berasal dari orang Indonesia sendiri. Jadi, kita tidak punya tradisi itu, jadi kemudian ketika ada gagasan dari Amin Rais untuk mengubah sistem Indonesia menjadi federasi atau desentralisasi atau otonomi yang sangat luas dengan lahirnya UU Pemda setelah kita meninggalkan orde baru itu nyata apa bedanya antara UU tadi dengan federalisme, di mana tadi ada satu yang disebut diserahkannya pemerintahan dari negara bagian ke pusat / central power tetapi ada sebagian yang tetap dipegang oeh negara bagian. Di Indonesia justru kebalikannya kekuasaan dari pemerintah pusat disebarkan ke daerah, itu sebetulnya ada suatu proses yang sama tapi dengan sudut pandang yang berbeda. Kemudian munculnya kembali gagasan federalisme sebetulnya untuk yang pertama kali dijawab dengan gagasan pembentukan DPD. Kedua, membuat UU pemda yang bernafaskan otonomi/desentraliasi sedemikian rupa menyerupai federalisme, Ketiga, menggagas kesetaraan antar provinsi dengan wujud dalam wadah keterwakilan masing-masing 4 orang tanpa memperhatikan jumlah dan besar sumber daya yang ada. Hal ini juga menunjukan adanya pengaruh dari AS.

Reposisi dan sejarah perwakilan daerah di Indonesia dapat dilihat pada tabel dibawah ini:

Tabel 1

Sejarah Perwakilan Daerah di Indonesia

\begin{tabular}{|c|c|c|c|c|}
\hline Periode & $\begin{array}{l}\text { Bentuk } \\
\text { Negara }\end{array}$ & $\begin{array}{l}\text { Nama } \\
\text { Badan }\end{array}$ & Jumlah & Keterangan \\
\hline $\begin{array}{l}\text { Pasca } \\
\text { Kemerdekaan } \\
(1945-1949)\end{array}$ & Republik & $\begin{array}{l}\text { Badan } \\
\text { Pekerja } \\
\text { Komite } \\
\text { Nasional }\end{array}$ & $\begin{array}{l}25 \text { orang: } \\
17 \text { dipilih } \\
\text { sidang, } 8 \\
\text { dipilih dari } \\
\text { daerah }\end{array}$ & $\begin{array}{l}\text { Anggota dari daerah inilah merupakan cikal } \\
\text { bakal terbentuknya unsur daerah dalam lembaga } \\
\text { Negara }\end{array}$ \\
\hline $\begin{array}{l}\text { RIS } \\
(1949)\end{array}$ & $\begin{array}{l}\text { Republik } \\
\text { Indonesia } \\
\text { Serikat } \\
\text { (RIS) }\end{array}$ & Senat & $\begin{array}{l}\text { Setiap } \\
\text { daerah } \\
\text { bagian } \\
\text { diwakili } 2 \\
\text { orang }\end{array}$ & 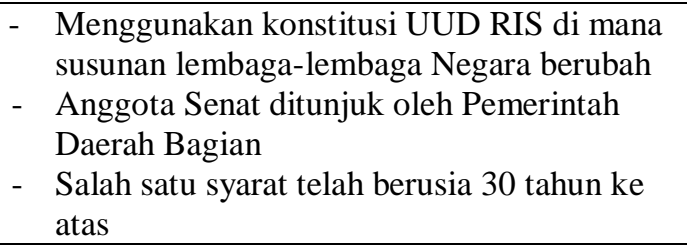 \\
\hline UUDS (1950) & Kesatuan & Dihapuskan & - & $\begin{array}{ll}\text { - } & \text { Konsekuensi digunakan UUDS - yang telah } \\
\text { disahkan Presiden Sukarno tahun } 1950- \\
\text { struktur kelembagaan berubah } \\
\text { - } \quad \text { Lembaga legislatif hanya DPR } \\
\text { - } & \text { Senat dihapus karena tidak ada daerah- } \\
& \text { daerah bagian dalam Negara Kesatuan }\end{array}$ \\
\hline
\end{tabular}

41 Ibid.

42 prosiding FGD sistem perwakilan yang diselenggarakan oleh Universitas Padjadjaran Bandung, 16 juni 2008, http://innajunaenah. wordpress.com, 01 Januari 2009 


\begin{tabular}{|c|c|c|c|c|}
\hline $\begin{array}{l}\text { Pasca Dekrit } \\
\text { Presiden } \\
(1959 \text {--1969) }\end{array}$ & Republik & $\begin{array}{l}\text { Utusan } \\
\text { Daerah }\end{array}$ & $\begin{array}{l}94 \text { orang } \\
\text { (PP No. } \\
150 / 1959 \text { ) }\end{array}$ & 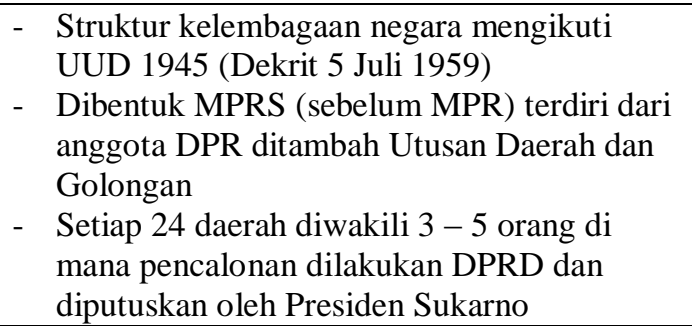 \\
\hline $\begin{array}{l}\text { Orde Baru } \\
(1969-1999)\end{array}$ & Republik & $\begin{array}{l}\text { Utusan } \\
\text { Daerah }\end{array}$ & $\begin{array}{l}131 \text { orang } \\
\text { ( } 27 \\
\text { propinsi) }\end{array}$ & 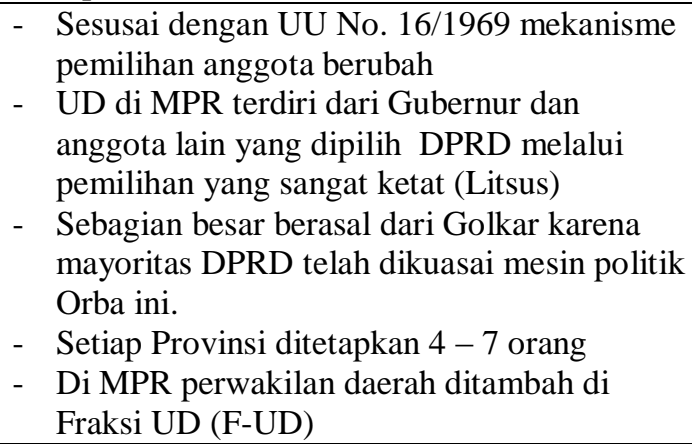 \\
\hline $\begin{array}{l}\text { Reformasi } \\
(1999-2004)\end{array}$ & Republik & $\begin{array}{l}\text { Utusan } \\
\text { Daerah }\end{array}$ & 135 orang & $\begin{array}{ll}\text { - } & \text { Berakhirnya Orba menguatkan keberadaan } \\
\text { Utusan Daerah (UU No. 4/1999 tentang } \\
\text { Susduk MPR, DPR, DPRD) } \\
\text { - } \quad \text { Penentuan anggota lewat proses pemilihan } \\
\text { DPRD (tanpa intervensi penguasa lagi) } \\
\text { - } & \text { Setiap Provinsi mengirim } 5 \text { anggota (seluruh } \\
\text { anggota MPR } 700 \text { orang) } \\
\text { - } & \text { SU MPR } 1999 \text { menghapuskan F-UD, } \\
& \text { anggota UD dimasukkan kepada partai-partai } \\
& \text { asalnya } \\
\text { - } & \text { ST MPR 2001 F-UD kembali diakui MPR }\end{array}$ \\
\hline $\begin{array}{l}\text { Amandemen } \\
\text { UUD } 1945 \\
\text { (sejak 2004) }\end{array}$ & Republik & $\begin{array}{l}\text { Menuju } \\
\text { Dewan } \\
\text { Perwakilan } \\
\text { Daerah }\end{array}$ & $\begin{array}{l}\text { Diwakili } 4 \\
\text { orang } \\
\text { (hasil } \\
\text { pemekaran } \\
\text { wilayah) }\end{array}$ & 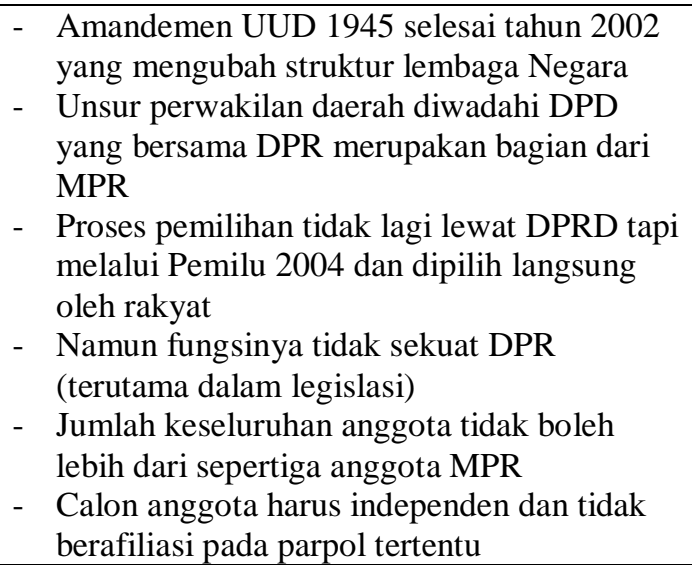 \\
\hline
\end{tabular}

Sumber data: Resume Naskah Akademis RUU DPD.

Di bidang otonomi daerah, perubahan pengaturan dari UU No. 22 th 1999 ke UU No. 32 tahun 2004, luas dirasakan sebagai maju ke belakang, bukan maju ke depan. Proses involusi sebagai "maju ke belakang" ini ditandai dengan kem-bali tergantungnya daerah kepada pusat di bidang-bidang yang tadinya diberikan otonomi untuk mengaturnya ke daerah. Misalnya, jika yang tadinya dengan UU No. 22/1999 DPRD Provinsi/Kota/Kabupaten bisa langsung mengeluarkan Perda, sekarang dengan UU No. 32/2004 harus mendapatkan perse-tujuan terlebih dahulu dengan pusat, dalam hal ini Depdagri, terutama untuk melihat apakah Perda yang dikeluarkan itu bertentangan atau tidak dengan undang-undang atau peraturan yang lebih 
tinggi yang berlaku. Status dan peranan pemprov sebagai perpanjangan tangan dari pusat, kendati tanpa hak otonomi yang diberikan, makin dipertegas dengan UU No. 32/2004, sementara pemda Kabupaten/Kota tidak bisa lagi langsung-langsung berhubungan dengan pusat, tetapi harus melalui koordinasi dari provinsi, meski kabupaten/kota punya hak otonomi. Juga, otonomi yang tadinya diberikan kepada Desa, sekarang diintervensi oleh pemerintah dengan ditempat-kannya seorang pegawai negeri untuk menjadi sekdes. ${ }^{43}$

Secara formal lembaga negara di bidang legislasi di tingkat nasional itu sekarang ada tiga, tetapi tiga yang a-simet-rik, dan tidak jelas bagaimana sesungguhnya hubungan struktural maupun institusional antara ketiga lembaga negara: MPR, DPR dan DPD itu. MPR dalam undang-undang dikatakan: terdiri atas anggota-anggota DPR dan DPD, sementara komposisi keanggotaannya ditentukan bahwa jumlah anggota DPD tidak boleh melebih sepertiga dari jumlah anggota DPR. Karenanya MPR bukanlah gabungan secara kelembagaan atau super-body dari DPR dan DPD. Rancu dan sekaligus mem-bingungkan. ${ }^{44}$

Mengambil Peran dalam Ruang Gerak Yang Sempit Terlepas dari kritik dan peran ideal di atas, kondisi nyata yang harus dihadapi ke depan adalah: 128 anggota DPD sudah terpilih bisa mengambil peran signifikan dalam sistem ketatanegaraan. Bivitri Susanti memberi catatan panjang lebar untuk itu, yang secara garis besar adalah:

a. DPD bisa menjadi "pintu masuk" partisipasi masyarakat dalam pembentukan undangundang.

b. Adanya DPD juga dapat mendorong adanya transparansi dalam kinerja parlemen secara keseluruhan.

c. DPD berpotensi bisa menjadi kekuatan politik penyeimbang DPR melalui wewenangnya dalam memberikan pertimbangan kepada DPR. ${ }^{45}$

Walaupun dalam UU No. 27 tahun 2009 yang menggantikan UU Susduk tersebut, dalam Pasal 150 ayat (1) dan (2) UU No 27 tahun 2009 telah memberikan perluasan kewenangan kepada DPD.

\section{Pasal 150}

(1) Pembicaraan Tingkat I dilakukan dengan kegiatan sebagai berikut:

a. pengantar musyawarah;

b. pembahasan daftar inventarisasi masalah; dan

c. penyampaian pendapat mini.

(2) Dalam pengantar musyawarah sebagaimana dimaksud pada ayat (1) huruf a:

a. DPR memberikan penjelasan dan Presiden menyampaikan pandangan apabila rancangan undang-undang berasal dari DPR;

b. DPR memberikan penjelasan serta Presiden dan DPD menyampaikan pandangan apabila rancangan undang-undang yang berkaitan dengan kewenangan DPD sebagaimana dimaksud dalam Pasal 71 huruf e berasal dari DPR;

43 http://mochtarnaim.wordpress.com, Op.Cit

44 Ibid

45 Bivitri Susanti, Ibid. 
c. Presiden memberikan penjelasan dan fraksi memberikan pandangan apabila rancangan undangundang berasal dari Presiden; atau

d. Presiden memberikan penjelasan serta fraksi dan DPD menyampaikan pandangan apabila rancangan undang-undang yang berkaitan dengan kewenangan DPD sebagaimana dimaksud dalam Pasal 71 huruf e berasal dari Presiden.

Hal mana sebagaimana yang pernah dikemukakan oleh Bivitri Susanti, bahwa Pasal mengenai DPD sekurang-kurangnya mengatur bahwa DPD juga mempunyai wewenang membahas dan ikut memutuskan mengenai seluruh RUU yang dibahas di DPR. Namun wewenang untuk mengajukan RUU, hanya terbatas pada RUU bidang tertentu yang berkaitan dengan otonomi daerah. Harus diatur ketentuan yang lebih jelas untuk prosedur pembahasan RUU antara DPR dan DPD. Nantinya RUU harus dibahas di salah satu kamar yang mengajukan terlebih dulu (DPR atau DPD). Apabila sudah disetujui di kamar yang satu, baru dikirim ke kamar yang lainnya. Apabila terjadi ketidaksepakatan di antara dua kamar, diadakan Sidang Gabungan antara DPD dan DPR. ${ }^{46}$

Kalau kita bicara soal ideal, berdasarkan konsep awal mengenai bikameral itu sendiri, DPD di masa yang akan datang harus mendapatkan fungsi dan peran utuh sebagai lembaga perwakilan rakyat sebagaimana halnya DPR. Dengan begitu, DPD juga mempunyai wewenang legislasi, pengawasan, dan anggaran, dengan mekanisme yang diatur sedemikian rupa sesuai karakteristik masing-masing dewan dan untuk mengatasi kebuntuan politik yang mungkin terjadi. ${ }^{47}$

Pasal mengenai DPD sekurang-kurangnya mengatur bahwa DPD juga mempunyai wewenang membahas dan ikut memutuskan mengenai seluruh RUU yang dibahas di DPR. Namun wewenang untuk mengajukan RUU, hanya terbatas pada RUU bidang tertentu yang berkaitan dengan otonomi daerah. Harus diatur ketentuan yang lebih jelas untuk prosedur pembahasan RUU antara DPR dan DPD. Nantinya RUU harus dibahas di salah satu kamar yang mengajukan terlebih dulu (DPR atau DPD). Apabila sudah disetujui di kamar yang satu, baru dikirim ke kamar yang lainnya. Apabila terjadi ketidaksepakatan di antara dua kamar, diadakan Sidang Gabungan antara DPD dan DPR. ${ }^{48}$

Secara substansial ketentuan yang ditetapkan dalam Pasal-Pasal Undang-Undang Susduk/ UU MPR, DPR, DPD dan DPRD maupun UU Pembentukan Peraturan Perundang-Undangan adalah berdasarkan ketentuan Undang-Undang Dasar. Hal ini berarti akan sangat sulit memperluas kewenangan DPD melalui perubahan Undang-Undang. Ada beberapa hal yang mungkin diubah terkait dengan pelaksanaan fungsi legislasi ${ }^{49}$ yaitu :

a. Perluasan ruang lingkup jenis rancangan Undang-Undang yang dapat diajukan oleh DPD.

46 Bivitri Susanti, Op.Cit.

47 Ibid

48 Ibid.

49 Mayoritas peserta diskusi menyampaikan prinsip-prinsip mutatis mutandis dalam peraturan perundangundangan. Dengan demikian selain penguatan melalui perubahan UU Susduk dan UU Pembentukan Peraturan Perundang-undangan harus ada upaya-upaya untuk melakukan perubahan UUD 1945. 
b. pemberdayaan DPD dilakukan dengan memberikan wewenang pengambilan keputusan atau secara sederhana melibatkan DPD dalam perubahan RUU pada pembicaraan tingkat I dan Tingkat II.

c. Substansi yang ditetapkan dalam Undang-Undang yang diusulkan oleh DPD betulbetul diperhatikan oleh DPR untuk menjadi substansi Undang-Undang.

d. Pertimbangan yang diberikan oleh DPD diperhatikan oleh DPR dan Presiden dalam menetapkan UU APBN, UU Pajak, pendidikan dan agama.

e. Hasil pengawasan atas pelaksanaan Undang-Undang dilakukan oleh DPD ditindaklanjuti oleh DPR. ${ }^{50}$

\section{Penutup}

Dari apa yang telah diketengahkan di atas, senyatanya banyak peran DPD dalam pelaksanaan asas desentralisasi dalam sistem otonomi daerah yang perlu untuk dimaksimalkan dengan mengkaji ulang ketentuan perundang-undangan terkait DPD, kinerja DPD, transparansi aktifitas DPD, DPRD dan kepala Daerah dalam memperjuangkan kepentingan daerah, serta pengalian aspirasi rakyat di daerah dengan cara-cara yang lebih elegant dan konstitusional.

\section{Daftar Pustaka}

\section{Buku:}

Assiddiqie Jimly, Format Kelembagaan negara dan Pergeseran Kekuasaan dalam UUD 1945 ", FH-UII Press, Yogyakarta, 2004,"

Afan Gaffar,"Politik Indonesia Transisi Menuju Demokrasi", Pustaka Pelajar, Jogyakarta, 1999.

,"Beberapa Salah Paham tentang Kebijakan Otonomi Daerah di Indonesia", makalah disampaikan dalam seminar tentang otonomi daerah di Jakarta, 25 April 1999.

Bambang Sunggono, Metode Penelitian Hukum, Radja Grafindo Persada, Jakarta, 2003,

Burhan Bungin, Metodologi Penelitian Kualitatif,, Radja Grafindo Persada, Jakarta, 2001,

Bayu Dwiwiddy jatmiko dan Sukesti, Laporan Penelitian: Perbandingan Pengaturan Lembaga Perwakilan Daerah Dalam Berbagai Undang-Undang Dasar Di Indonesia. FH UMM, 2011/2012.

50 Http://www.watchterminal.net. Op.Cit. 
Catur Wido Haruni, dalam Laporan Penelitian "Kajian Kritis Terhadap Penyelesaian Sengketa Pemilihan Kepala Daerah Secara Langsung ditinjau dari UU No. 32 Tahun 2004 Tentang Pemerintahan Daerah”, DP2M UMM, 2009

Eep Syaefullah Fatah,"Penghianatan Demokrasi Ala Orde Baru”, Rosda, Bandung, 2001,

M. Yahya Harahap, Beberapa Tinjauan Tentang Permasalahan Hukum, Jurnal Yuridika, Volume 12,4 Maret 2005

Mansur Fakih," Catatan Perjalanan Panjang Menuju Demokrasi, Pengantar bagi dadang Juliantara, teretas Jalan demokrasi", Kanisius, Jogyakarata, 1998,

Muh.Mahfud MD,’Demokrasi dan Konstitusi di Indonesia”,Rineka Cipta, Jakarta, 2000,

Morissan, "Hukum Tata Negara RI Era Reformasi",Ramdina Prakarsa, Jakarta, 2005,

PKK Unibraw - DPD RI, Laporan Penelitian "konstruksi perwakilan daerah dalam sistem ketatanegaraan indonesia", Malang, 2009:

S.H.Sarunjang, "Pemerintah Daerah di Berbagai Negara Sebuah Pengantar", Pustaka Sinar Harapan, Jakarta, 2002,

Suharto, Penuntutan Dalam Praktek Peradilan, Sinar Grafika, Jakarta,2006, , Hukum Pidana Materiil, Sinar Grafika, Jakarta, 2004,

Wijaya, Angger Jati,"Reformasi Pemerintahan Daerah",Pustaka Pelajar, Yogyakarta, 2000,

Zainal Abidi, Hukum Pidana I, Sinar Grafika, Jakarta, 2006,

Zainudin, Sosiologi Hukum, Sinar Grafika, Jakarta, 2005,

\section{Perundang-undangan:}

Undang Undang Dasar Negara Republik Indonesia Tahun 1945

Undang Undang Nomor 10 Tahun 2004 Tentang Pembentukan Peraturan Perundangundangan

Undang Undang Nomor 32 tahun 2004 Tentang Pemerintahan Daerah

Undang Undang No. 10 Tahun 2008 Tentang Pemilihan Umum Anggota Dewan Perwakilan Rakyat, Dewan Perwakilan Daerah, Dan Dewan Perwakilan Rakyat Daerah

Undang Undang No. 27 tahun 2009 Tentang MPR, DPR, DPD dan DPRD 


\section{Internet}

Http://www.yipd.or.id,

Http://www.scribd.com,

Http://www.wikipedia.com,

Htttp://www.priamaironline.com.

Http://medizton.wordpress.com,.

Http://www.saldiisra.web.id.

Http://www.parlemen.net,

Http://www.pshk.or.id,

Http://innajunaenah.wordpress.com,

Http://www.watchterminal.net.

Http://mochtarnaim.wordpress.com, 